\title{
Covid-19 Pandemisi Sürecinde Uzaktan Eğitim İle İlgili Yaşanan Sorunların Öğrenci Bakış Açısına Göre AHP Yöntemi İle İncelenmesi
}

\author{
Öğr. Gör. Hazal AKBAL \\ Niğde Ömer Halisdemir Üniversitesi, Zübeyde Hanım Sağlık Hizmetleri MYO, Tıbbi \\ Hizmetler ve Teknikler Bölümü \\ hazalakbal@ohu.edu.tr, Orcid ID 0000-0002-51299773
}

\section{H. İnan AKBAL}

Ege Üniversitesi, Bilgisayar ve Öğretim Teknolojileri Eğitimi Ana Bilim Dalı, Yüksek Lisans Öğrencisi huseyininanakbal44@hotmail.com, Orcid ID 0000-0002-47915692

\section{Öz}

Tüm dünya ülkeleri tarafından önlenmeye çalışılan Covid-19 pandemisi sürecinde başta sağlık olmak üzere bankacılık, turizm, ulaşım gibi sektörlerde virüsün etkisini azaltmak amacıyla düzenlemeler yapılmıştır. Bu sektörlerden biri de eğitimdir. Yüz yüze eğitimin bu süreçte olumsuzluklar yaratması nedeniyle eğitim sürecini aksatmayacak farklı yöntemlere yönelinmiştir. Öğrenci ve eğitimci arasındaki mekân ve zaman kavramını ortadan kaldırarak bilgi iletişiminde kolaylık sağlayan uzaktan eğitimin sınırlılıklarından dolayı öğrenme sürecinde birtakım sorunlar yaşanabilmektedir. Çalışmada öğrenci bakış açısına göre uzaktan eğitimde yaşanan en önemli sorunun tespit edilmesi amacıyla çok kriterli karar verme tekniklerinden biri olan AHP yöntemi kullanılmıştır. Bu doğrultuda Nisan-Mayıs 2020 tarihlerinde bir sağlık hizmetleri meslek yüksekokulunda eğitim gören tıbbi dokümantasyon ve sekreterlik programı öğrencileri ile görüşülmüştür. Çalışmanın sonucunda uzaktan eğitim sürecinde ortaya çıkan en önemli sorunun fiziki koşullar ile ilgili olduğu tespit edilmiştir. İçinde bulunulan pandemi süreci ile ilgili uzaktan eğitimde yaşanan sorunların belirlenmesi ve önceliklendirilmesine dair yapılan çalışmalara rastlanmamıştır. Bu anlamda, çalışmanın literatüre ve uzaktan eğitim sürecinde aktif rol oynayan eğiticilere katkı sunacağ düşünülmektedir.

Anahtar Kelimeler: Analitik Hiyerarşi Prosesi, Çok Kriterli Karar Verme Yöntemleri, Uzaktan Eğitim, Covid-19

JEL Sınıflandırması: C30, C44, I23 

AHP Yöntemi İle İncelenmesi

\title{
Investigation of the Problems Related to Distance Education in the Covid-19 Pandemic Process by the AHP Method According to the Student's View
}

\begin{abstract}
In the Covid-19 pandemic process, countries of the world regulations were made in sectors such as health, banking, tourism, and transportation to reduce the effect of the virus. One of these is education sector. Since face-to-face education creates negativity, different methods have been applied that will not hinder the process. Due to the limitations of distance education, which provides convenience in information communication, many problems are experienced in the learning process. According to the student's view, AHP method was used to identify the most important problem related to distance education. April and May 2020, medical documentation and secretarial program students were interviewed. At the end of the study, it was determined that the most important problem was related to physical conditions. Studies have been not found to identify and prioritize problems related to distance education during the pandemic process. In this respect, it is thought that the study will contribute to the literature and to educators.
\end{abstract}

Keywords: Analytic Hierarchy Process, Multi Criteria Decision Making Methods, Distance Education, Covid-19.

JEL Classification: C30, C44, I23

\section{Giriş}

İçinde bulunduğumuz çağ bilgi, teknoloji ya da bilim çağı olarak adlandırılmaktadır. Çağın gereklerine uygun olarak bilimde ortaya çıkan gelişmeler geleneksel eğitim yöntemlerinin yanı sıra farklı alternatiflerin ortaya çıkmasını sağlamıştır. Uzaktan eğitim yöntemi de bu alternatif yöntemlerden birisidir. Uzaktan eğitim ve eğitimde kullanılan teknoloji arasındaki ilişki oldukça kuvvetli bir ilişkidir. Uzaktan eğitimde ilk olarak mektup kullanılmış olup daha sonra hayatımıza giren radyo, televizyon, bilgisayar ve internet gibi teknolojilerle uzaktan eğitim sürdürülmeye başlanmıştır (Cabı ve Ersoy, 2017, s. 420).

Farklı alanlarda bulunan eğitimci ve öğrencileri bir araya getiren uzaktan eğitim yöntemi, zamanın etkin kullanımını konusunda fayda sağlamaktadır. Uzaktan eğitim yükseköğretim basamağında hızlı bir şekilde yaygınlaşmaktadır. Yükseköğretim basamağında yer alan üniversiteler toplumların kalkınmasında büyük rol oynayan eğitim kurumlarıdır. Bu eğitim kurumları alanında uzman iş gücü yetiştirmek amacıyla mesleki bilginin yanı sıra mesleğe dair uygulamalı eğitimler de sunmaktadır. Bu 

the AHP Method According to the Student's View

anlamda uzaktan eğitim, üniversite öğrencilerine mesleki bilgi ve tecrübe kazandırmada faydalanılan yöntemlerdendir. Öğrenci bu yolla istediği zamanda istediği mekânda istediği derse katılma imkânı bulmaktadır. Ancak uzaktan eğitim getirdiği faydaların yanı sıra pek çok sorunu da beraberinde getirmektedir. Özellikle uzaktan eğitime geçiş sürecinin hızlı olduğu, bu süreç hakkında yeteri kadar bilgi sahibi olunamadığ durumlarda sorunlar artış göstermektedir.

Dünya genelinde 26 Kasım 2020 tarihi ile itibariyle Dünya Sağlık Örgütüne (WHO) 60.074.174 tespit edilen Covid-19 vakası bildirilmiştir. Covid-19'a bağlı ölüm sayısının ise 1.416.292 olduğu tespit edilmiştir (WHO, 2020). Tüm dünyayı etkisi altına alan Covid-19 Pandemisi ile pek çok sektör çalışma prensibinde değişikliklere gitmiştir. $\mathrm{Bu}$ sektörlerden birisi de eğitim sektörüdür. İlk ve orta dereceli okullar ile üniversiteler yüz yüze eğitime ara vererek uzaktan eğitim yöntemiyle eğitim ve öğretim faaliyetlerini sürdürmeye başlamıştır. Özellikle ilk defa uzaktan eğitim ile tanışan üniversite öğrencileri bu süreçte pek çok sorunla karşı karşıya kalmaktadır.

2019-2020 yılı verilerine göre Sağlık Hizmetleri Meslek Yüksekokulu sayısı 118 olarak tespit edilmiştir. Bu eğitim birimlerinde kayıtlı olan toplam 184274 öğrenci bulunmaktadır. 3658 öğretim elemanı ise eğitim sunmaktadır (Yükseköğretim Bilgi Yönetim Sistemi, 2020). Çalışmanın yapıldığı kurum bir sağlık hizmetleri meslek yüksekokulu olup sağlık alanında kalifiye eleman yetiştirmeyi amaçlamaktadır. Sağlık alanında yapılan hizmet sunumu doğrudan insan sağlığına etki edeceğinden bu kurumlarda yetişen öğrencilerin alanında uzman, kaliteli ve nitelikli bilgiyle donanması büyük önem taşımaktadır. Bu doğrultuda yapılan çalışmanın amacı kurumda eğitim gören ve ilk defa uzaktan eğitimle tanışan tıbbi dokümantasyon ve sekreterlik programı öğrencilerinin uzaktan eğitim sürecinde yaşadığı sorunları tespit ederek sorunların önceliklendirilmesidir.

Konuya ilişkin olarak yapılan literatür taramasında uzaktan eğitim sürecinde yaşanan sorunlarla ilgili pek çok çalışma olmasına karşın, içinde bulunduğumuz pandemi sürecinde uzaktan eğitimle ilgili yaşanan sorunların saptanması ve önceliklendirilmesine ilişkin çalışmalara rastlanmamıştır. Bu durum çalışma konusunun belirlenmesinde etkili olmuştur. Ayrıca spesifik bir alan olan sağlık alanında hizmet sunan bir meslek yüksekokulunda çalışmanın yapılması çalışmanın özgün yönünü ortaya koymaktadır.

\section{Uzaktan Eğitim Kavramı}

Uzaktan eğitim kavramı, farklı ortamlarda bulunan öğrenci, eğitmen ve eğitim malzemelerinin iletişim teknolojilerinin yardımıyla bir araya geldiği bir eğitim faaliyeti olarak tanımlanabilmektedir (Etlioğlu ve Tekin, 2020, s. 35). Günümüzde nitelikli uygulamaları olan uzaktan eğitim, dünyada ilk defa 1728 tarihinde posta yoluyla Boston gazetesinde steno derslerinin duyurumu ile başlamıştır. Başlarda radyo, televizyon ve posta gibi iletişim araçları kullanılarak yapılan öğretim tek yönlü bilgi aktarım özelliği 

AHP Yöntemi İle İncelenmesi

taşırken, internetin kullanımı ile birlikte bu aktarım çift yönlü bir süreç haline gelmiştir (Ak, Oral ve Topuz, 2018, s. 75). Elektronik ortamlarda sunulan eğitim malzemeleri ile düşük maliyet, zaman ve mekân bağımsızlığı, fursat eşitliği gibi pek çok fayda sağlanmıştır. Uzaktan eğitim, içinde bulunduğu dönemin teknolojik trendine uygun çeşitli yöntemlerle dünyada yaygın olarak kullanılmaktadır (Etlioğlu ve Tekin, 2020, s. 35). Uzaktan eğitimde kullanılan araçlar teknolojinin gelişimi ile birlikte değişime uğramaktadır. Günümüzde yaygın olarak kullanılan uzaktan eğitim aracı internettir. Bilgisayar, telefon, tabletler ise internet kullanımını sağlayan araçlardır (Cırık, 2016, s. 172).

Yükseköğretim kurumları çerçevesinde uzaktan öğretimin gelişmiş ülkelerdeki oranı \% 10'un altında yer alırken Türkiye, Çin, Güney Afrika, Tayland ve Madagaskar gibi gelişmekte olan ülkelerde \%30'un üzerinde bir paya sahiptir (Türkiye'nin Yükseköğretim Stratejisi, 2007). Ülkemizde 2019-2020 y1lları arasında uzaktan öğretim önlisans programlarında okuyan toplam öğrenci sayısı Tablo 1'de gösterilmiştir. Bu verilere göre uzaktan öğretim önlisans programlarında okuyan toplam 27.261 öğrenci bulunmaktadır. Bu öğrencilerin 25.249'u devlet üniversitelerinde eğitim alırken 2.012'si vakıf üniversitelerinde okumaktadır (Yükseköğretim Bilgi Yönetim Sistemi, 2020).

Tablo 1. Uzaktan Öğretim Önlisans Programı Öğrenci Sayıları, 2019-2020

\begin{tabular}{llll}
\hline & Erkek & Kız & Toplam \\
\hline $\begin{array}{l}\text { Devlet } \\
\text { Üniversitesi }\end{array}$ & 14611 & 10638 & 25249 \\
\hline $\begin{array}{l}\text { Vakıf } \\
\text { Üniversitesi }\end{array}$ & 1165 & 847 & 2012 \\
\hline Toplam & 15776 & 11485 & 27261 \\
\hline
\end{tabular}

Kaynak: Yükseköğretim Bilgi Yönetim Sistemi, 2020

İletişimde sürekli öğrenmeye ve benzeri görülmemiş teknolojik yeniliklere ihtiyaç duyulması, uzaktan eğitim yaklaşımlarını eğitim uygulamasının ön planına itmiştir (Garrison, 2000, s. 1). Uzaktan öğretim, öğrencilerin herhangi bir zamanda veya herhangi bir yerde öğrenmeleri için elverişli bir firsat yaratmıştır (Kataoka ve Mertala, 2017 , s. 424). Uzaktan eğitim veren üniversiteler yüz yüze eğitim alamayanlar, okula geri dönmek isteyenler, ileri yaşlarda mesleki ve kişisel eğitim almak isteyenlerin taleplerini karşılamak amacıyla bu eğitim yöntemini sunmaktadır (Figaredo ve Álvarez, 2019, s. 119). Uzaktan eğitimi tercih eden diğer öğrenci grupları ise kırsal kesimde yaşayan öğrenciler, hasta veya hastaneye yatırılan çocuklar, üstün zekâlı çocuklar, seyahat eden aileler ve düzenli sınıflarda sorun yaşayan öğrencilerdir (Mupinga, 2005, s. 106). Farklı mekânlarda bulunan öğrenci ve eğiticinin ihtiyaç duyduğu görsel, yazılı ve sözlü iletişim internet aracılığıla sağlanabilmektedir. Bu sayede öğrenci istediği zamanda istediği derse katılabilmektedir. $\mathrm{Bu}$ durum ise zamanın etkin kullanılması açısından fayda sağlamaktadır. Uzaktan eğitim, özellikle yükseköğrenimde daha hızlı 
bir biçimde yaygınlaşmaktadır (Günter, Güneş ve Demir, 2012, s. 56). Uzaktan eğitimin kullanıcılara pek çok fayda sağlamasının yanı sıra birtakım olumsuzluklara da neden olabileceği söylenebilmektedir. Örneğin kontrolsüz bir şekilde sanal ortamda araştırma yapan bir öğrenci, zararlı ve gereksiz birtakım bilgilere ulaşacaktır. Bu durum hem zaman kaybına hem de bilgi kirliliğine neden olacaktır. Bilgisayar kullanımına dayalı etik kuralların açık olmaması da sanal içerikli suçlara yol açmaktadır. (Cırık, 2016, s. 177).

\section{Yöntem}

Çalışmada uzaktan eğitimde yaşanan sorunları belirlemek için öncelikle literatür araştırması yapılmıştır. Karaca, Topal ve Aldır (2011), uzaktan eğitimde en sık gözlemlenen sorunları idari yapı, organizasyon değişiklikleri, teknik uzmanlık, destek ve alt yapı, öğrenci destek servisi, sosyal etkileşim, iletişim, maaş ve zaman, değerlendirme, teknoloji tehdidi ve telif hakkı olarak sınıflandırmıştır. Bu çalışmada ise Karaca, Topal ve Aldır (2011) tarafından belirtilen sınıflandırma ile öğrencilerden alınan görüşler doğrultusunda 3 ana kriter ve 9 alt kriterden oluşan hiyerarşik bir sınıflandırma yapılmıştır.

Çalışma bir sağlık hizmetleri meslek yüksekokulunda eğitim gören tıbbi dokümantasyon ve sekreterlik programı öğrencileri ile 2020 yılının Nisan ve Mayıs aylarında gerçekleştirilmiştir. Uzaktan eğitim sürecinde yaşanan sorunlara ilişkin kriterler belirlenirken tıbbi dokümantasyon ve sekreterlik programı öğrencileri ile görüşmeler yapılarak onların deneyim ve bilgilerinden faydalanılmıştır. Bu görüşme 1şığında fiziki koşullar, idari hizmetler ve öğretim elemanları ile ilgili olmak üzere toplam 3 ana kriter ve 9 alt kriter belirlenmiştir. Bu alt kriterlere ilişkin bilgiler Tablo 2'de sunulmuştur.

Tablo 2. Uzaktan Eğitimde Yaşanan Sorunlara İlişkin Kriterler

\begin{tabular}{ll}
\hline Kriterler & Açıklama \\
\hline Kısıtlı çalışma alanı & $\begin{array}{l}\text { Etkili öğrenme sürecinin gerçekleşebilmesi için } \\
\text { gerekli olan çalışma ortamının sağlanamamasıdır. }\end{array}$ \\
\hline Yetersiz iletişim araçları & $\begin{array}{l}\text { Uzaktan eğitim imkânlarından faydalanmak için } \\
\text { bilgisayar, akıllı telefon, internet, mikrofon gibi }\end{array}$ \\
& iletişim araçlarının yetersiz olmasıdır. \\
\hline Eksik Kaynak & Covid-19 pandemi sürecinde okulların tatil ilan \\
& edilmesi ile birlikte öğrencilerin ders kitabı, \\
& yardımcı kaynak, ders notu gibi malzemeleri \\
& öğrenim gördükleri ilde bırakarak evlerine \\
& dönmeleri nedeniyle etkili öğrenmenin \\
& gerçekleşememesidir. \\
\hline İhtiyaç duyulan idari personel gücünün \\
eksikliğinden kaynaklanan ulaşım problemleridir.
\end{tabular}



AHP Yöntemi İle İncelenmesi

\begin{tabular}{|c|c|}
\hline Ö̆ğrenci işlerine ulaşım & $\begin{array}{l}\text { Öğrenci işlerinde görev alan personel gücünün } \\
\text { eksikliğinden kaynaklanan ulaşım problemleridir. }\end{array}$ \\
\hline $\begin{array}{l}\text { Yetersiz } \\
\text { hizmetleri }\end{array}$ & $\begin{array}{l}\text { Uzaktan eğitim sürecinde karşılaşılan sorunlar için } \\
\text { sunulan destek hizmetlerinin yetersiz olmasıdır. }\end{array}$ \\
\hline İletişim & $\begin{array}{l}\text { Öğretim elemanı ve öğrenci arasında çok yönlü } \\
\text { haberleşmenin sağlanamamasıdır. }\end{array}$ \\
\hline $\begin{array}{l}\text { Yetersiz } \\
\text { materyalleri }\end{array}$ & $\begin{array}{l}\text { Ders içeriklerinin kalite, anlaşılırlık, uygunluk ve } \\
\text { güncellikten uzak olmasıdır. }\end{array}$ \\
\hline Ölçme ve değerlendirme & $\begin{array}{l}\text { Bilgisini uzaktan eğitim sistemi üzerinden } \\
\text { yeterince ifade edemeyen öğrencilerin öğretim } \\
\text { elemanının gözünden kaçarak yanlış veya eksik } \\
\text { değerlendirilmesidir. }\end{array}$ \\
\hline
\end{tabular}

\subsection{Analitik Hiyerarşi Prosesi}

Karar vericiler için birçok alternatifin bulunduğu durumlarda karar verme süreci zor olabilmektedir. Bu süreci kolaylaştırmak için çok kriterli karar verme tekniklerinden biri olan Analitik Hiyerarşi Prosesi (AHP) kullanılmaktadır (Kandemir, Kazan ve Karaman, 2019, s. 549). 1970'lerde Thomas L. Saaty tarafindan geliştirilen AHP, birçok kriter barındıran karmaşık problemlerin çözümlenmesinde kullanılan bir karar verme tekniğidir. Bu teknik karmaşık problemleri, amaç, kriter, alt kriter ve alternatifler arasında kurulan ilişkiyi belirten bir hiyerarşik yapıda modellemeye firsat vermektedir. Karar vericinin hem nesnel hem de öznel düşüncelerini karar verme sürecine dâhil edebilmesi yöntemin en önemli özelliğidir (Kuruüzüm ve Atsan, 2001, s. 84).

AHP yönteminde karar verme probleminin ilk adımı hiyerarşik yapının oluşturulması ile başlar. Hiyerarşik yapı oluşturulurken Şekil l'de gösterildiği gibi en üstte ana amaç, daha sonra kararı etkileyecek olan kriterler ve en altta karar alternatifleri bulunur (Ersoy, Çelik, Yeşilkaya, 2017, s. 63). 


\section{Şekil 1: AHP'nin Hiyerarşik Yapısı}

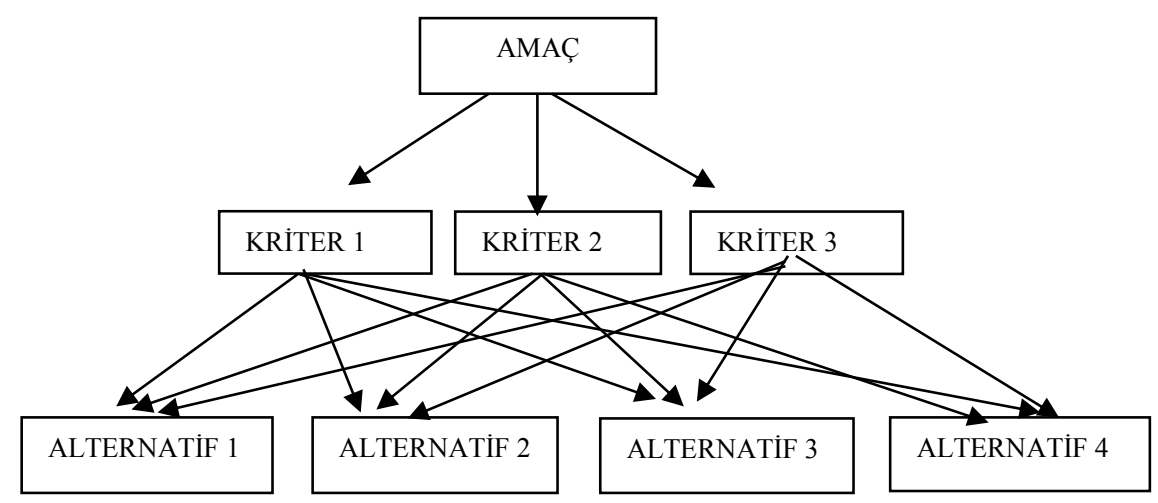

Kaynak: Ge \& Liu, 2019: 358.

Analitik Hiyerarşi Prosesinin ikinci adımını ikili karşılaştırma matrisleri oluşturur. Bu adımda hiyerarşik yapı içerisinde bulunan elemanların bir üst kademede bulunan elemanlara göre önem sırasının belirlenebilmesi için ikili olarak karşılaştırılır. İkili karşılaştırma matrislerinin oluşturulmasında Tablo 3'te gösterilen Saaty tarafından geliştirilen 1-9 puanlı tercih ölçeğinden yararlanılır (Kuruüzüm ve Atsan, 2001, s. 87).

Tablo 3: AHP'de Kullanılan Tercih Ölçeği

\begin{tabular}{ll}
\hline Önem Derecesi & Tanım \\
\hline $\mathbf{1}$ & Eşit derecede önemli \\
\hline $\mathbf{3}$ & Biri diğerine göre az önemli \\
\hline $\mathbf{5}$ & Kuvvetli derecede önemli \\
\hline $\mathbf{7}$ & Çok kuvvetli derecede önemli \\
\hline $\mathbf{9}$ & Aşırı derecede önemli \\
\hline $\mathbf{2 , 4 , 6 , 8}$ & Ortalama değerler \\
\hline
\end{tabular}

Kaynak: Saaty, 1980: 54

AHP, bu süreçte birden çok kişinin görüşlerinin değerlendirilmesine imkân tanıdığı için görüşlerde uzlaşma sağlanması gerekir. Bu durumda grup üyelerinin konu üzerinde tartışarak uzlaşmaya varması, uzlaşmayı sağlamak için aracıya başvurulması, her ikili yargıyı matematiksel yöntemle toplamak gibi yöntemlere başvurulur. AHP yönteminde sıklıkla kullanılan ise geometrik ortalama alma işlemidir (Öztürk, Çekerol, 2016, s. 153; Önder ve Önder, 2015, s. 36 ).

İkili karşılaştırma matrisleri oluşturulduktan sonra üçüncü adımda her bir sütun değerinin ilgili sütun toplamına bölünmesi ile elde edilen normalize matrisler 

AHP Yöntemi İle İncelenmesi

oluşturulur. Normalize matriste her bir satırın ortalaması alınarak öncelik değerleri hesaplanır (Özder, Bedir ve Eren, 2019, s. 22).

Dördüncü adım tutarlılık oranının (TO) hesaplandığı adımdır. Öncelik değerlerinin hesaplanmış olması önemlerin her zaman doğru bulunduğu anlamı taşımamaktadır. Karar vericilerin yanlış değerlendirme yapmış olabileceği düşünülerek doğru karar verebilmek için tutarlılık analizi yapılır. TO=Tİ/Rİ formülü ile hesaplanır. Burada Tİ, Tutarlılık İndeksi, Rİ ise Rassal İndeksi ifade etmektedir. Tİ= $(\lambda \max -n) /(n-$ 1) formülü ile hesaplanmaktadır. Rİ değeri bulunurken Tablo 4'te gösterildiği gibi Rassal İndeks tablosundan uygun değer seçilerek hesaplama yapılır (Ömürbek, Karaatlı ve Yetim, 2014, s. 194). Tutarlılık oranı hesaplanırken ilk olarak karşılaştırma matrisi ile öncelik değerleri çarpılarak toplamı alınır ve ağırlıklı toplam vektör (ATV) değeri hesaplanır. ATV değeri kendisine karşılık gelen öncelik değerine bölünerek ulaşılan sonuçların ortalaması alınır. Böylelikle $\lambda$ max değeri bulunmuş olur (Doğan ve Gencan, 2013, s. 76).

Tablo 4: Rassal İndeks Değeri

\begin{tabular}{|c|c|c|c|c|c|c|c|c|c|c|c|c|c|c|c|}
\hline $\mathrm{n}$ & 1 & 2 & 3 & 4 & 5 & 6 & 7 & 8 & 9 & 10 & 11 & 12 & 13 & 14 & 15 \\
\hline $\mathrm{R}$ & 0 & 0 & 0.5 & 0.8 & 1.1 & 1.2 & 1.3 & 1.4 & 1.4 & 1.4 & 1.5 & 1.5 & 1.5 & 1.5 & 1.5 \\
\hline$\dot{\mathrm{I}}$ & & & 2 & 9 & 1 & 5 & 5 & 0 & 5 & 9 & 2 & 4 & 6 & 7 & 9 \\
\hline
\end{tabular}

Kaynak: Saaty, 2008: 129.

Tutarlılık Oranının 0,10'dan küçük olması beklenir. 0,10'dan büyük olduğu durumlarda kararın tekrar gözden geçirilmesi gerekir (Yıldırım ve Güzel, 2019, s. 74).

Son adım seçenekler için nihai ağırlıkların belirlendiği aşamadır. Her bir alternatif için son ağırlıklar hesaplanır. En yüksek ağırlığa sahip alternatif amacımızı en iyi gerçekleştiren alternatiftir (Öztürk, Çekerol, 2016, s. 155).

\section{Uygulama ve Bulgular}

Çalışmanın yapıldı̆̆ı kurum sağlık alanında nitelikli insan gücü yetiştirmeyi amaçlayarak mesleki eğitim sunan bir sağlık hizmetleri meslek yüksekokuludur. Okul, başta tıbbi dokümantasyon ve sekreterlik programı olmak üzere ilk ve acil yardım, yaşlı bakımı, optisyenlik programlarında okuyan öğrencilere eğitim hizmeti sunmaktadır. Çalışma tıbbi dokümantasyon ve sekreterlik programı öğrencileri ile sınırlı tutularak 2020 yılının Nisan ve Mayıs aylarında gerçekleştirilmiştir. Uzaktan eğitim sürecinde yaşanan en önemli problemin tespit edilmesi amacıyla gönüllü olarak çalışmaya katılmayı kabul eden tıbbi dokümantasyon ve sekreterlik programı öğrencilerinden oluşan 60 kişi, belirlenen kriterleri, Saaty tarafindan geliştirilen önem ölçeğine göre karşılaştırmıştır. Karşılaştırma matrisi oluşturulurken, 60 öğrencinin kriterlere verdiği puanların ortalaması alınmıştır. 

the AHP Method According to the Student's View

Uzaktan Eğitimde Yaşanan Sorunlara İlişkin Kriterler Şekil 2'de görüldüğü gibi 3 kriter ve 9 alt kriterden oluşmaktadır. Buna göre kriterler fiziki koşullar, idari hizmetler ve öğretim elemanları ile ilgili kriterler olarak belirlenmiştir. Fiziki koşullar ile ilgili alt kriterler; kısıtlı çalışma alanı, yetersiz iletişim araçları ve eksik kaynaklardır. İdari hizmetler ile ilgili alt kriterler; idari personele ulaşım, öğrenci işlerine ulaşım ve yetersiz destek hizmetleridir. Öğretim elemanları ile ilgili alt kriterler; iletişim, yetersiz ders materyalleri, ölçme ve değerlendirmedir.

\section{Şekil 2: Uzaktan Eğitimde Yaşanan Sorunlara İliş̧kin Hiyerarşik Yapı}

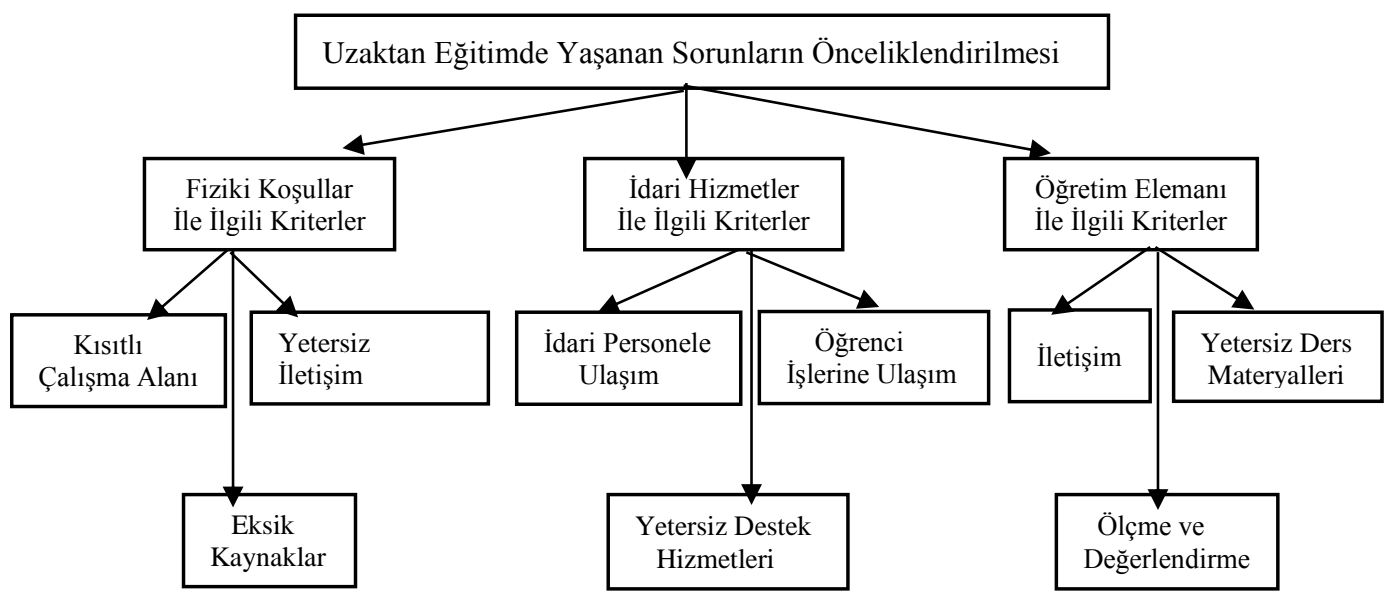

Hiyerarşik yapı oluşturulduktan sonra Saaty tarafından geliştirilen tercih ölçeği dikkate alınarak ana kriterler önem sırasına göre karşılaştırılmıştır. Belirlenen ana kriterler için Tablo 5'te belirtildiği gibi öncelikle karşılaştırma matrisleri oluşturulmuştur. Daha sonra normalleştirme işlemi yapılarak her bir kritere ait öncelik değeri hesaplanmıştır.

Tablo 5: Ana Kriterlerin Önem Dereceleri

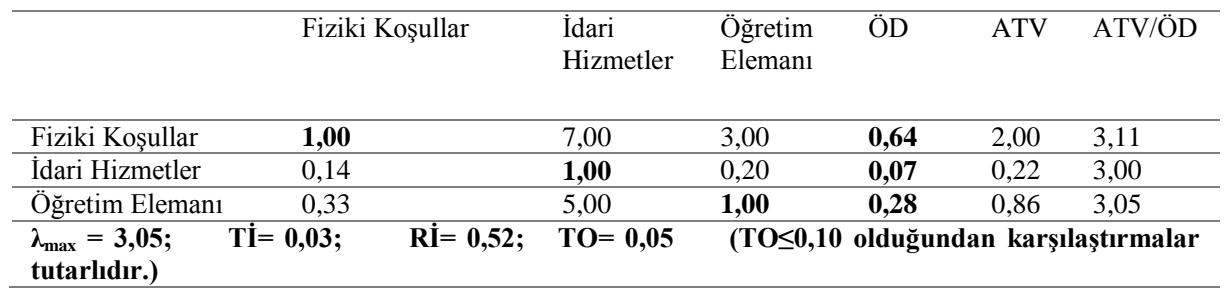



AHP Yöntemi İle İncelenmesi

Tıbbi dokümantasyon ve sekreterlik programı öğrencileri ile yapılan görüşmeler sonucunda ana kriterler önem sırasına göre 0,64 ile fiziki koşullar, 0,28 ile öğretim elemanı ve 0,07 ile idari hizmetler ile ilgili kriterler olarak değerlendirilmiştir. $\mathrm{Bu}$ durumda öğrencilerin uzaktan eğitim sürecinde en çok fiziksel koşullardan kaynaklanan sorunlar yaşadıkları tespit edilmiştir. Öğrencilerin bildirmiş olduğu görüşlerde ne kadar tutarlı olduğunu tespit etmek için Tutarlılık oranına (TO) bakılmıştır. TO oranı 0,05 olarak tespit edilmiştir. $\mathrm{TO} \leq 0,10$ olduğundan öğrencilerin vermiş olduğu kararlarda tutarlı olduğu görülmüştür. Ana kriterlerin karşılaştırılmaları yapıldıktan sonra her ana kritere bağlı alt kriterler de kendi aralarında karşılaştırılmıştır. Her ana kritere bağlı alt kriterler Tablo 6, Tablo 7 ve Tablo 8 'de gösterildiği gibi öncelik sirasına göre karşılaştırılmıştır.

Tablo 6: Fiziki Koşullar İle İlgili Alt Kriterlerin Önem Dereceleri

\begin{tabular}{llllllc}
\hline & $\begin{array}{l}\text { Kısıtlı } \\
\text { Çalışma } \\
\text { Alanı }\end{array}$ & $\begin{array}{l}\text { Yetersiz } \\
\text { İletişim } \\
\text { Araçları }\end{array}$ & $\begin{array}{l}\text { Eksik } \\
\text { Kaynaklar }\end{array}$ & ÖD & ATV & ATV/ÖD \\
\hline Kısıtlı Çalışma Alanı & $\mathbf{1 , 0 0}$ & 3,00 & 5,00 & 0,63 & 1,94 & 3,07 \\
\hline Yetersiz İletişim Araçları & 0,33 & $\mathbf{1 , 0 0}$ & 3,00 & 0,26 & 0,79 & 3,03 \\
\hline Eksik Kaynaklar & 0,20 & 0,33 & $\mathbf{1 , 0 0}$ & 0,11 & 0,32 & 3,01 \\
\hline $\boldsymbol{\lambda}_{\max }=\mathbf{3 , 0 3 ;} \mathbf{T} \dot{\mathbf{I}}=\mathbf{0 , 0 2} ; \mathbf{R} \dot{\mathbf{I}}=\mathbf{0 , 5 2} ;$ & $\mathbf{T O}=\mathbf{0 , 0 3}$ & $\mathbf{( T O} \leq \mathbf{0 , 1 0}$ olduğundan karşılaştırmalar tutarlıdır. $)$ \\
\hline
\end{tabular}

Öğrencilerin bakış açısına göre fiziki koşullar ile ilgili kriterlere ait alt kriterler incelendiğinde 0,63 ile etkili öğrenme sürecinin gerçekleşebilmesi için gerekli olan çalışma ortamının kısıtlı olması en önemli sorun olarak tespit edilmiştir. 0,26 ile uzaktan eğitim imkânlarından faydalanmak için bilgisayar, akıllı telefon, internet, mikrofon gibi iletişim araçlarının yetersiz olması ikinci önemli sorun olarak değerlendirilmiştir. 0,11 önem derecesi ile değerlendirilen ders kitabı, yardımcı kaynak, ders notu gibi malzemelerin eksik veya olmaması durumu ise en az önem derecesine sahip kriter olarak karşımıza çıkmıştır. Alt kriterlere ait Tutarlılık Oranına bakıldığında bu oran 0,03 olarak bulunmuştur. $\mathrm{TO} \leq 0,10$ olduğundan öğrencilerin kararlarında tutarlı olduğu tespit edilmiştir.

Tablo 7: İdari Hizmetler İle İlgili Alt Kriterlerin Önem Dereceleri

\begin{tabular}{lllllll}
\hline & $\begin{array}{l}\text { İdari } \\
\text { Personele } \\
\text { Ulaşım }\end{array}$ & $\begin{array}{l}\text { Öğrenci } \\
\text { İşlerine } \\
\text { Ulaşım }\end{array}$ & $\begin{array}{l}\text { Yetersiz } \\
\text { Destek } \\
\text { Hizmetleri }\end{array}$ & ÖD & ATV & ATV/ÖD \\
\hline İdari Personele Ulaşım & $\mathbf{1 , 0 0}$ & 0,25 & 0,16 & 0,08 & 0,25 & 3,01 \\
\hline Öğrenci İşlerine Ulaşım & 4,00 & $\mathbf{1 , 0 0}$ & 0,25 & 0,24 & 0,75 & 3,07 \\
\hline Yetersiz Destek Hizmetleri & 6,00 & 4,00 & $\mathbf{1 , 0 0}$ & 0,67 & 2,15 & 3,20 \\
\hline $\boldsymbol{\lambda}_{\max }=\mathbf{3 , 0 9 ;} \quad \mathbf{T I}=\mathbf{0 , 0 5} ;$ & $\mathbf{R} \dot{\mathbf{I}}=\mathbf{0 , 5 2} ;$ & $\mathbf{T O}=\mathbf{0 , 0 9}$ & $\mathbf{( T O} \leq \mathbf{0 , 1 0}$ olduğundan karşılaştırmalar tutarlıdır. $)$ \\
\hline
\end{tabular}



the AHP Method According to the Student's View

İdari hizmetler ile ilgili alt kriterler değerlendirildiğinde en önemli sorun 0,67 ile yetersiz destek hizmetleri olarak tespit edilmiştir. 0,24 ile öğrenci işlerine ulaşım ve 0,08 ile idari personele ulaşım önem derecesi düşük sorunlar olarak karşımıza çıkmaktadır. Alt kriterlere ait bildirilen görüşlerin tutarlılık oranı 0,09 olarak hesaplanmıştır. Öğrencilerin idari hizmetler ile ilgili bildirdikleri görüşlerde tutarlı oldukları görülmüştür.

Tablo 8: Öğretim Elemanı İle İlgili Alt Kriterlerin Önem Dereceleri

\begin{tabular}{|c|c|c|c|c|c|c|}
\hline & İletişim & $\begin{array}{l}\text { Yetersiz Ders } \\
\text { Materyalleri }\end{array}$ & $\begin{array}{l}\text { Ölçme ve } \\
\text { Değerlendirme }\end{array}$ & ÖD & ATV & ATV/ÖD \\
\hline İletişim & $\mathbf{1 , 0 0}$ & 0,50 & 5,00 & 0,33 & 1,00 & 3,01 \\
\hline $\begin{array}{ll}\text { Yetersiz } & \text { Ders } \\
\text { Materyalleri } & \end{array}$ & 2,00 & 1,00 & 7,00 & 0,59 & 1,78 & 3,02 \\
\hline $\begin{array}{l}\text { Ölçme ve } \\
\text { Değerlendirme }\end{array}$ & 0,20 & 0,14 & $\mathbf{1 , 0 0}$ & 0,07 & 0,22 & 3,00 \\
\hline $\begin{array}{l}\lambda_{\max }=3,01 \\
\text { tutarlıdır.) }\end{array}$ & $=0,01$; & $\mathrm{R} \dot{\mathrm{I}}=\mathbf{0 , 5 2}$ & $(\mathrm{TO} \leq \mathbf{0 , 1 0}$ & luğun & n karş & ıştırmalar \\
\hline
\end{tabular}

Öğretim elemanları ile ilişkili alt kriterler incelendiğinde 0,59 önem derecesi ile ders içeriklerinin kalite, anlaşılırlık, uygunluk ve güncellikten uzak olması en önemli sorun olarak görülmüştür. 0,33 önem derecesi ile öğretim elemanının öğrenciyle etkili iletişim kuramaması ise ikinci önemli sorun olarak tespit edilmiştir. En az önem derecesine sahip kriter ise öğretim elemanının öğrenciyi ölçme ve değerlendirmedeki eksiklikler olmuştur. $\mathrm{Bu}$ alt kriterlere ait tutarlılık oranı 0,01 olarak hesaplanmıştır. Öğrencilerin görüşlerinde tutarlı olduğu görülmüştür.

\section{Tartışma ve Sonuç}

Tüm dünyayı etkisi altına alan Covid-19 pandemi sürecinde yüz yüze eğitimin olumsuzluklara yol açabileceği sebebiyle uzaktan eğitim sürecine geçilmiştir. Etkili ve kaliteli bir eğitim sürecini hedefleyen uzaktan eğitimde öğrenciler farklı sorunlarla karş1 karşıya kalmaktadır. Öğrencilerin karşılaştıkları bu sorunları onların bakış açısıyla değerlendirerek en önemli sorunun tespit edilmesi amacıyla tıbbi dokümantasyon ve sekreterlik programı öğrencileri ile görüşülmüştür. $\mathrm{Bu}$ görüşme doğrultusunda fiziki koşullar, idari hizmetler ve öğretim elemanları ile ilgili 3 ana kriter ve bu ana kriterlere bağlı toplam 9 alt kriter AHP yöntemi ile 60 öğrencinin kriterlere verdiği puanların ortalaması alınarak önem sırasına göre önceliklendirildirilmiştir. Çalışmanın sonunda uzaktan eğitim sürecinde ortaya çıkan en önemli sorunun fiziki koşullar ile ilgili olduğu sonucuna varılmıştır.

Fiziki koşullara ait alt kriterler incelendiğinde çalışma ortamının kısıtlı olması en önemli sorun olarak görülmüştür. Öğrencilerin etkili bir eğitim hizmeti alabilmesi için çalışma ortamının eğitim-öğretim faaliyetlerine uygun bir biçimde düzenlenmesi gerekir. Uzaktan eğitim sürecinde öğrencilere sunulan eğitim materyalleri her ne kadar 

AHP Yöntemi İle İncelenmesi

kaliteli olsa da öğrencinin bu materyallere ulaşacağı fiziksel ortam mevcut değilse öğrencinin öğrenme süreci sekteye uğrayacaktır. Aydınlatma, 1sıtma gibi fiziksel unsurlardan uzak ve kişisel çalışma ortamlarının bulunmayışı öğrencilerin odaklanma sorunu yaşamasına neden olabilmektedir. Uzaktan eğitim sürecinde yaşanan ikinci önemli sorun ise iletişim araçlarının yetersiz olmasıdır. Öğrencilerin büyük kısmı bilgisayar, internet, akıllı telefon gibi iletişim araçlarına sahip değildir. Uzaktan eğitimin sürdürülmesinde büyük önem taşıyan bu iletişim araçlarına sahip olmayan öğrenciler kendilerine sunulan eğitim materyallerinden mahrum kalmaktadır.

Uzaktan eğitim süreci her yönüyle değerlendirilmesi gereken bir konudur. Uzaktan eğitimi sürdürebilecek alt yapı hizmetleri ile eğiticinin elinde öğrenme faaliyetini gerçekleştirebilecek her türlü donanıma sahip araç ve gereçlerin bulunması bu sürecin etkin bir şekilde yürütülebilmesi için yeterli olmamaktadır. Bu süreçte öğrencilerin karşılaşabileceği sorunlar ve engellerin tespit edilerek ortadan kaldırılması veya minimum düzeye indirilmesi etkin bir öğrenme süreci için faydalı olacaktır.

$\mathrm{Bu}$ çalışma spesifik bir alan olan sağlık alanında hizmet sunan bir meslek yüksekokulunda yürütülmüştür. Çalışma Covid-19 pandemi sürecinin etkilerini göz önüne alarak uzaktan eğitimde yaşanan sorunların belirlenmesi ve bu sorunların öğrenci bakış açısı ile önceliklendirilmesi açısından literatürdeki diğer çalışmalardan ayrılmaktadır. Çalışma Covid-19 virüsünün Ülkemizde ortaya çıkmaya başladığı ve uzaktan eğitim sürecine adapte olmaya çalışıldığı ilk zamanlarda bir önlisans programı ile sınırlı tutularak yürütülmüştür. İleride yapılacak olan çalışmalarda yükseköğretim kurumlarının tümünün araştırmaya dahil edildiği ve kriterlerin çeşitlendirildiği daha geniş kapsamlı araştırmaların yapılması düşünülebilir.

\section{Kaynakça}

Ak, A., Oral, B. ve Topuz, V. (2018). Marmara Üniversitesi Teknik Bilimler Meslek Yüksekokulu Uzaktan Öğretim Sürecinin Değerlendirilmesi. Bilim, Eğitim, Sanat ve Teknoloji Dergisi (BEST Dergi), 2(1), 71-80.

Cabı, E., Ersoy, H. (2017). Yükseköğretimde Uzaktan Eğitim Uygulamalarının İncelenmesi: Türkiye Örneği. Yüksekögrretim ve Bilim Dergisi, 7(3), 419-429.

Cırık, M. (2016). Uzaktan Eğitimin Üstün Zekâlı Öğrencilerin Eğitimindeki Yeri. Açıkögretim Uygulamaları ve Araştırmaları Dergisi (AUAd), 2(3), 170-187.

Doğan, N. Ö. ve Gencan, S. (2013). Seyahat Acentası Yöneticilerinin Bakış Açısıyla En Uygun Otel Seçimi: Bir Analitik Hiyerarşi Prosesi (AHP) Uygulaması. Erciyes Üniversitesi İktisadi ve İdari Bilimler Fakültesi Dergisi, 41, 69-88.

Ersoy, M., Çelik, M. Y. ve Yeşilkaya, L. (2017). Mesafe Ölçme Yöntemlerinin Analitik Hiyerarşi Proses Yöntemiyle Değerlendirilmesi. Mesleki Bilimler Dergisi, 6 (2), 59-79. 

the AHP Method According to the Student's View

Etlioğlu, M. ve Tekin, M. (2020). Elektronik Öğrenmede Öğrenci Tutum Ve Akademik Başarı Arasındaki İlişkide Öğrenci Merak Ve Kaygısının Aracılık Rolü. Selçuk Üniversitesi Sosyal Bilimler Enstitüsü Dergisi, 4, 34-38.

Figaredo, D. D. ve Álvarez, J. F. (2019). The challenges of Distance Universities in An İncreasingly Digital Context. Open Praxis, 11(2), 119-128.

Garrison, R. (2000). Theoretical Challenges For Distance Education In The 21st Century: A Shift From Structural To Transactional Issues. International Review of Research in Open and Distance Learning, 1(1), 1-17.

Ge, Z. ve Liu, Y. (2019). Analytic Hierarchy Process Based Fuzzy Decision Fusion System For Model Prioritization And Process Monitoring Application. IEEE Transactions on Industrial Informatics, 15(1), 357-365.

Günter, T., Güneş, E. Ö. ve Demir, E. O. (2012). Türkiye'deki Meslek Yüksekokullarında Uzaktan Eğitim. Yükseköğretim ve Bilim Dergisi, 2(1), 54-62.

Kandemir, A. Ş., Kazan, H. ve Karaman, E. (2019). İmalat Sektöründe Mesleki Eğitim Veren Girişimlere Göre Hedeflenen Beceri Türü Seçimi Üzerine Bir Uygulama: Analitik Hiyerarşi Süreci. TURAN-SAM Uluslararası Bilimsel Hakemli Dergisi, 11(41), 549-557.

Karaca, O., Topal, M. ve Aldır, Z. (2011). Uzaktan Eğitim Sorunları. Internatiınal Science and Technology Conference, Istanbul, 7-9 December 2011.

Kataoka, H. ve Mertala, M. (2017). The role of Educators And Their Challenges In Distance Learning in New Millennium. Palma Journal, 16(3), 423-426.

Kuruüzüm, A. ve Atsan, N. (2001). Analitik Hiyerarşi Yöntemi Ve İşletmecilik Alanındaki Uygulamaları. Akdeniz İktisadi İdari Bilimler Dergisi, 1, 83-105.

Mupinga, D. M. (2005). Distance Education in High Schools: Benefits, Challenges, and Suggestions. The Clearing House: A Journal Of Educational Strategies. Issues and Ideas, 78(3), 105-109, DOI: 10.3200/TCHS.78.3.105-109.

Ömürbek, N., Karaatlı, M. ve Yetim, T. (2014). Analitik Hiyerarşi Sürecine Dayalı Topsis ve Vikor Yöntemleri İle Adım Üniversitelerinin Değerlendirilmesi. Selçuk Üniversitesi Sosyal Bilimler Enstitüsü Dergisi Dr. Mehmet YILDIZ Özel Sayısı, 189-207.

Önder, G. ve Önder, E. (2015). Analitik Hiyerarşi Süreci, Editörler Yıldırım, BF., ve. Önder, E., İsletmeciler, Mühendisler ve Yöneticiler İçin Operasyonel, Yönetsel ve Stratejik Problemlerin Çözümünde Çok Kriterli Karar Verme Yöntemleri içinde (ss.21-74). Bursa: Dora Yayıncılık. 

AHP Yöntemi İle İncelenmesi

Özder, E. H., Bedir, N. ve Eren, T. (2019). Yükseköğretimde Araştırmacı Seçiminde Çok Ölçütlü Karar Verme Yöntemlerinin Kullanılması: Bir İnceleme. Alanya Akademik Bakış, 3(1), 19-33.

Öztürk, Ö. ve Çekerol, G. S. (2016). Anadolu Üniversitesi Açıköğretim Fakültesi Bürosu Yeri Seçiminin Analitik Hiyerarşi Süreci İle Belirlenmesi. Sosyal Bilimler Dergisi, 50, 148-161.

Saaty, T. L. (1980). The Analytic Hierarchy Process. U.S.A: McGraw-Hill Comp.

Saaty, T. L. (2008). The Analytic Hierarchy And Analytic Network Measurement Processes: Applications to Decisions Under Risk. European Journal of Pure and Applied Mathematics, 1(1), 122-196.

Türkiye'nin Yükseköğretim Stratejisi

https://www.yok.gov.tr/Documents/Yayinlar/Yayinlarimiz/Turkiyenin-

yuksekogretim-stratejisi.pdf. Ankara, Şubat 2007. Erişim tarihi: 26.11.2020

WHO (2020). WHO Coronavirus Disease (COVID-19) Dashboard. https://covid19.who.int/. Erişim tarihi: 27.11.2020.

Yıldırım, B. I. ve Güzel, Ö. (2019). Seyahat Acentelerinin Turist Rehberi Seçim Kriterlerinin Analitik Hiyerarşi Süreci (AHS) Yöntemi İle Değerlendirilmesi. Anatolia: Turizm Araştırmaları Dergisi. 30(1), 69 - 81.

Yükseköğretim Bilgi Yönetim Sistemi (2020). Eğitim Birimlerine Göre Öğrenci ve Öğretim Elemanları Sayıları. https://İstatistik.Yok.Gov.Tr. Erişim tarihi:27.11.2020.

Yükseköğretim Bilgi Yönetim Sistemi (2020). Öğrenci Sayıları Özet Tablosu. https://istatistik.yok.gov.tr. Erişim tarihi: 27.11.2020. 